\title{
Examining the Level of Foreign Language Classroom Anxiety among ELT Undergraduate Students: A Quantitative Approach
}

\author{
John Peter Wappa ${ }^{1,2}$, Clement Pembi ${ }^{3}$ \\ ${ }^{1,2}$ Department of English Language Education, College of Continuing Education, Adamawa State Polytechnic, Yola, Adamawa \\ State, Nigeria. \\ ${ }^{3}$ Department of English, Federal College of Education, Yola, Adamawa State, Nigeria
}

\begin{abstract}
The study is aimed at investigating the nature of anxiety experienced by university ELT major undergraduate students; a representative number of 60 students from the ELT department at Cyprus University (pseudonym) in Turkish Republic of Northern Cyprus (TRNC) participated. The quantitative data for the study was collected using two universally used instruments, the foreign language classroom anxiety scale (FLCAS) and the foreign language reading anxiety scale (FLRAS). A quantitative approach was adopted for the study and the data obtained was statistically analysed using SPSS version 25 . The general findings of the study indicate that the general foreign language classroom anxiety (FLCA) is slightly higher than the foreign language reading anxiety (FLRA) as experienced by the students. In addition, it shows no significant difference between ages in both FLCA and FLRA. Finally, it equally shows that there is no statistical difference between male and female in both FLCA and FLRA.
\end{abstract}

Keywords: Anxiety, foreign language, reading, ELT, FLCA, FLRA, Quantitative

\section{INTRODUCTION}

$\mathrm{T}$ he English language in most cases is referred to as Foreign Language especially in countries other than the countries of origin, as it is becoming the world's lingua franca (Coleman, 2006 in Santos, Cenoz \& Gorter, 2018). Foreign language learning has been given a serious attention especially by European institutions because educational system attaches so much importance to foreign language. As a result of this, students world over are expected to be proficient in foreign language, as it is becoming a medium of instruction in most schools because most institutions design their curriculum as such (Bergström, Klatte, Steinbrink \& Lachmanna, 2016; Santos, Cenoz \& Gorter, 2018; Gurney, 2018; Tan \& Nguyen, 2018). Such that now the issue of anxiety sets in, though before now, the nature of anxiety in foreign language classroom has long attracted the attention of scholars and have "been well documented" (Jin \& Dewale, 2018; Yan \& Horwitz, 2008). It is also worth noting that anxiety is one of the most frequent problems observed in foreign language learning (Yastibaş \& Yastibaş, 2015).

Learners of foreign language feel uneasy in the foreign language classroom as they find it difficult to speak because they try to avoid errors; such therefore affects their classroom participations. Nervousness is a problem, and it occurs when they are engaged in any of the language skills (Horwitz, Horwtiz \& Cope, 1986; Cheng, 2002; Luo, 2014; Chow, Chiu $\&$ Wong, 2018), this is witnessed in the clinical experience of Horwitz, Horwtiz \& Cope (1986) with speaking and listening, while speaking was identified as to have shown the most frequent level of anxiety. The learners experience anxiety when they find it difficult to discriminate the sounds, the structure and even the content of message of their target language. This at times makes the learners write the wrong answers in exams even when they know the correct answer, this occurs because their brain at that particular moment goes blank; sometimes, they find it difficult to recall some simple spellings because they are anxious or nervous. The situation tempers with their apprehension as against when they are relaxed, it affects the communication ability employed by the learner in the classroom. Anxiety therefore impedes the learners' performance in the foreign language classroom; this is because of the tension they are experiencing at that moment and it stops them from understanding the lesson because of the nervousness they are experiencing. Meanwhile, in a learning environment, everybody is bound to feel anxious, be it the teachers or students. In addition, anxiety affects language input by contributing to learner's performance during language lessons (Yastibaş \& Yastibaş, 2015; Horwtiz, 2013; Horwitz, Horwtiz \& Cope, 1986).

Foreign language learners' outcome differ, this is because of individual differences, this most at times manifests in their learning motivations, the usable resources, language aptitude, and attitudes towards the target language community. Anxiety therefore serves as major barriers between the foreign language learners and the target language (Çağatay, 2015; Dörnyei \& Ryan, 2015; Yastibaş \& Yastibaş, 2015).

This study therefore, is different from other studies which were done on foreign language classroom anxiety and foreign language reading anxiety. Most of the previous studies focused more on foreign language anxiety negative emotion such as causes and consequences, with some dwelling on the position orientation, considering students' and teachers' emotion support for foreign language classroom anxiety (Jin 
\& Dewale, 2018). The present study aims at determining the level of foreign language classroom anxiety and foreign language reading anxiety experienced by ELT major undergraduate students at Cyprus University (Pseudonym). This research is made unique and contributes to the literature through its focus on factual variables, which include such as the experience of anxiety by ELT major students, the comparison between foreign language classroom anxiety and foreign language reading anxiety by students both according to age and gender, which as noticed has not been studied in the context of Cyprus.

\subsection{Foreign Language Anxiety}

Anxiety serves as main barriers between the foreign language learners and the target foreign language (Çağatay, 2015; Yastibaş \& Yastibaş, 2015). Foreign language in some sort is characterised by anxiety when communicating and reading, especially with pronunciation, are classified as foreign language anxiety. Anxiety occurs when learners are in distress concerning their inability to be themselves due to their limitations in the new language (Jin \& Dewaele, 2018; Horwtiz, 2007). Based on findings from several studies, it is indicated that the foreign language anxiety interferes with the learners' foreign language learning and performance in various domains as it has negative effects on the learners' cognitive, academic as well as learner's socialization. Invariably, the learners' chance to develop proficiency in the target language is weakened favouring anxiety and creating a vicious circle. Students who are anxious or are nervous in any way try to avoid communicating with others. They tend to miss classes, and in a writing situation, they prefer writing at home or outside the class, as they fear that their foreign language output may be judged negatively and such can equally undermine even the teacher's effort (Horwtiz, Hortiz \& Cope, 1986; Dewaele \& MacIntyre, 2014; Jin \& Dewaele, 2018).

Investigations show that the occurrence of anxiety in foreign language learning varies based on individual's different anxiety levels, which are connected to their demographic background both social and cultural, their proficiency levels and their foreign language learning experience. Their responding is considered based on personality traits: broad personality traits and lower-order personality aspects. The broad traits indicate that the only personality traits that present a significant negative path to foreign language anxiety is extraversion, and it has a negative relationship with foreign language anxiety as individuals with high psychoticism and emotional stability suffer less anxiety in the foreign language classroom during speaking. Meanwhile, personality is equally associated with emotional intelligence (Trait E). Foreign language learners' classroom anxiety could be high possibly from cognitive and evaluation of the classroom environment as it has both internal and social dimension (MacIntyre \& Charos, 1996; Dewaele, Petrides \& Fuenham, 2008; MacInyre, 2017; Jin \& Dewaele, 2018). Similarly, reading in foreign language can create anxiety, though foreign language anxiety can be independent of the target language. The sources of foreign language reading anxiety is related to unfamiliar topics, unfamiliar scripts, writing system as well as learners' uneasiness about comprehension. The foreign language reading anxiety can equally affect students' academic grades (Saito, Garza, \& Horwitz, 1999; Zhao, Dynia, \& Guo, 2013).

Young (1992) identified six factors of anxiety intuitively associated with foreign language classroom: motivation, cultural factors, the students' coping skills, self-concept, beliefs and language learning, and the specific teaching methodology, which the students are exposed to. There are additional other fundamental factors which Young (1991) gathered from literature and are consider too as contributing factors to foreign language learning anxiety: personal and interpersonal anxiety, learner beliefs about language learning, instructor's beliefs about language teaching, instructor-learner interactions, classroom procedures and language testing.

\subsection{Methods for Coping with Foreign Language Anxiety}

Studies done on foreign language anxiety experienced by students during learning also looked at proffering solution to it. Horwtiz et al. (1986)'s FLCAS has been the primary instrument that is always used in finding consistent level of anxiety across target language. Few strategies have been identified for solving students' anxiety these include preparation, relaxation, positive thinking, peer seeking and then resignation. The preparation stage shows students' efforts to overcome anxiety, which they are experiencing, relaxation is another strategies of minimizing anxiety, while next is to think positive to get relieved. Tension can be controlled too by finding other anxious students in the class; and lastly, the students get relieved by becoming reluctant to do anything to alleviate their language anxiety (Horwtiz et al., 1986; Kondo \& Ling, 2004).

\subsection{Empirical Studies on Anxiety}

Baş and Özean (2018) in investigating foreign language anxiety among high school and university students, a comparative study, considered gender, current educational status, parental educational status and monthly family income as variables using foreign language anxiety scale. It was discovered that there was little difference of the anxiety level among the students in terms of gender in the personality construct $(\mathrm{t}(672)=-.160, \quad \mathrm{p}>0 / 05), \quad$ communication and evaluation all have $(\mathrm{t}(672)=-1.513, \mathrm{p}>0.05)$, there was no significant difference as far gender is concerned in terms of the students' anxiety. While their current educational status shows some statistical difference between the high school and the university students. The high school students indicated higher level of foreign language learning anxiety in all the construct with $\mathrm{M}_{\text {personal }}=38.61 ; \quad \mathrm{M}_{\text {communication }}=39.33$ and $\mathrm{M}_{\text {evaluation }}=31.60$, then the findings from the family anxiety of the high school and that of the university students in terms of monthly income has no statistical difference as well. Therefore, the study shows no statistical difference between 
the gender, as Alsowat (2016); Nahavandi and Mukundan (2013) state that gender is an ineffective variable that might not affect foreign language learning anxiety in the classroom confirm the findings.

In addition, Toubot, Seng and Abdullah (2018) investigated the speaking anxiety level in EFL by the fourth-year Libyan English Undergraduate Students. The focused on main three factors: communication apprehension, fear of negative evaluation and low self-confidence as identified by Horwtiz et al. (1986). The scholars adopted the Foreign Language Speaking Anxiety Scale (FLSAS) to collect quantitative data to measure anxiety level. A sample of 300 fourth-year students from the department of English from three Universities in Libya were used. The findings showed low self-confidence factor having the highest average score of 181.25, the fear of negative evaluation factor has an average of 167.8 , while communication apprehension is the third factor with an average of 140.57. The students' level of speaking anxiety therefore is high particularly when they speak English without preparation; this is due to their fear of error or making mistakes when they speak English before their classmates.

Similarly, Chow, Chiu and Wong (2018) tested the relationships between foreign language (FL) reading and listening anxiety. It established connections between foreign language anxiety (FLA) and its cognitive, affective and behavioural correlates in English. The research used three hundred and six (306) Chinese undergraduate students learning English as a Foreign Language (EFL) for the study. Chow, Chiu and Wong (2018) measured them through administered questionnaire. Regression analyses used in the study indicated that EFL performance and motivation were major factors that can exclusively project EFL reading and listening anxiety level.

A negative relationship was identified between EFL performance with EFL reading and listening anxiety by (Saito, Garza \& Horwtiz, 1999; Sellers, 2000; Elkhafaifi, 2005), and this was supported by research that poor performance can create anxious feelings (MacIntyre, 1995; Onwuegbuzie, Bailey \& Daley, 1999). When individuals have no confidence in themselves as been good in language skills for communication and interaction, their Foreign Language Anxiety goes higher. In addition, learning strategies can be a source of language anxiety as they are associated with learners' effective processing of the Foreign Language. Nevertheless, in this study, the strategies failed to explain main portions of variance in anxiety skills after the effects of learning motivation and performance were accounted for. However, the negative correlations identified between metacognitive/social strategies and FLLA/FLRA indicates a close relationship.

Santos, Cenoz and Gorter (2018) focused on university students' attitudes towards English and their anxieties concerning the use of English, specifically, the attitudes and anxiety level of business and education students towards English. The study shows that business students had more positive attitudes towards English than the education students, this could possibly be because Business views English as a requisite in the department. From the findings, female business students have relatively positive attitudes as compared to male business students but also a higher level of anxiety. The results confirm those of Bolton and Kuteeva (2012) regarding the variances across disciplines discovered in the survey carried out in Sweden.

Reflective practices play a role in improving the efficiency of learning and teaching methods as video-stimulated recall technique was adopted as a motivating factor for language learners to reflect on their oral production skills (Cinkara, 2016). Cinkara (2016) in an experimental study used pre-test, post-test and V-SRI sessions (only in control group). Then, applying the Foreign Language Classroom Anxiety Scale (FLCAS) to control and treatment groups before and after an eight-week module during the period, the treatment group of the students went through video-stimulated recall interviews. From the statistical analyses, it revealed that pre- and post-test FLCAS scores differ, only with the treatment group but not within the control group. Stimulated recall was found to be an effective reflective tool, which supports students in detecting and reflecting upon the symptoms and causes of anxiety in the classroom. The technique has been used in language teaching to study the cognitive processes experienced by students during classroom tasks (Gass, nd). In this, Cinkara (2016) applied the protocol as an instrument for stimulating reflection in students, and consequently, for providing the learners with an anxiety-free setting. The findings advised that the stimulated recall method would provide insights into learners' cognitive processing as well as prove to be a reliable means for stimulating reflection.

Anxiety is one thing students experience in their studies and battle to handle. Elkhafaifi (2005), Sellers (2000), Saito, Garza and Horwtiz (1999) are some few studies carried on anxiety. Some of the studies considered students' poor performance because of anxious feelings (MacIntyre, 1995; Onwuegbuzie, Bailey \& Daley, 1999). Considering other studies which have been done, to the best of my knowledge, there is no study of this nature on Cyprus University, (Pseudonym) students, specifically, the ELT Department. Therefore, the need for this study. The study is aimed at investigating the nature of anxiety experienced by ELT undergraduates at Cyprus University (Pseudonym), which its results will contribute eminently to the growing literature in the field, serve as a reference a material for scholars and above all, it helps teachers and students to overcome anxiety in teaching and learning situation busting the learners' learning abilities. It will serve as a guide for curriculum and syllabus designers for institutions on the categories of activities to prepare for foreign language learners. Low anxiety promotes high inputs leading the better learning (see 
Krashen, 1985). Therefore, the following research questions are intended at achieving the aim of the study when answered.

1. Do the students of ELT experience any form of anxiety in the foreign language classroom?

2. What are the levels of foreign language classroom anxiety (FLCA) and foreign language reading anxiety (FLRA) experienced by the ELT students at Public University?

3. Do their foreign language classroom anxiety and foreign language reading anxiety differ according to gender?

\section{METHOD}

\subsection{Context and Participants}

The study adopted a descriptive type of general survey research design with a quantitative approach. Quantitative approach is adopted for the study because it would help get objective data for the study, "the paradigm ensures validity by the process of rigorous clarification, definition or use of pilot experiments" (Atieno, 2009:13). It is a distinctive way of approaching to solve the real world problem as its view is considered as being 'realist' or 'positivist'. The technique mainly is good for generalizations (Holton \& Burnett, 2005; Muijs, 2013). The current study was conducted during the 2018/2019 fall semester with sixty (60) first year undergraduate students from the ELT Department at Cyprus University (Pseudonym) in Turkish Republic of Northern Cyprus (TRNC. Sixteen (16) males and thirty-nine (39) females participated, meanwhile, five (5) did not indicate their gender. The random sample selection was used, considering the diverse nature of the school.

Table 1: Demographic information

\begin{tabular}{|c|c|c|c|c|c|}
\hline \multicolumn{2}{|c|}{ Participants' Age } & Frequency & Percent & $\begin{array}{c}\text { Valid } \\
\text { Percent }\end{array}$ & $\begin{array}{c}\text { Cumulative } \\
\text { Percent }\end{array}$ \\
\hline \multirow{4}{*}{ Valid } & $18-22$ & 55 & 91.7 & 91.7 & 91.7 \\
\hline & $23-27$ & 4 & 6.7 & 6.7 & 98.3 \\
\hline & $28-32$ & 1 & 1.7 & 1.7 & 100.0 \\
\hline & Total & 60 & 100.0 & 100.0 & \\
\hline \multicolumn{6}{|c|}{ Participants' Gender } \\
\hline \multirow{3}{*}{ Valid } & Male & 16 & 26.7 & 29.1 & 29.1 \\
\hline & Female & 39 & 65.0 & 70.9 & 100.0 \\
\hline & Total & 55 & 91.7 & 100.0 & \\
\hline \multirow{2}{*}{\multicolumn{2}{|c|}{ Missing }} & 5 & 8.3 & & \\
\hline & & 60 & 100.0 & & \\
\hline \multicolumn{6}{|c|}{ Participants' Nationalities } \\
\hline \multirow{4}{*}{ Valid } & Armenia & 1 & 1.7 & 1.7 & 1.7 \\
\hline & Bosnia & 1 & 1.7 & 1.7 & 3.3 \\
\hline & Cyprus & 7 & 11.7 & 11.7 & 15.0 \\
\hline & Egypt & 1 & 1.7 & 1.7 & 16.7 \\
\hline
\end{tabular}

\begin{tabular}{|c|c|c|c|c|c|}
\hline \multirow{7}{*}{} & India/Kuwaiti & 1 & 1.7 & 1.7 & 18.3 \\
\cline { 2 - 6 } & Iran & 1 & 1.7 & 1.7 & 20.0 \\
\cline { 2 - 6 } & Palestine & 1 & 1.7 & 1.7 & 21.7 \\
\cline { 2 - 6 } & Syria & 1 & 1.7 & 1.7 & 23.3 \\
\cline { 2 - 6 } & Turkey & 46 & 76.7 & 76.7 & 100.0 \\
\cline { 2 - 6 } & Total & 60 & 100.0 & 100.0 & \\
\hline \multirow{5}{*}{ Valid } & Arabic & 4 & 6.7 & 6.7 & 6.7 \\
\cline { 2 - 6 } & Bosnien & 1 & 1.7 & 1.7 & 8.3 \\
\cline { 2 - 6 } & Persian & 1 & 1.7 & 1.7 & 10.0 \\
\cline { 2 - 6 } & Turkish & 54 & 90.0 & 90.0 & 100.0 \\
\cline { 2 - 6 } & Total & 60 & 100.0 & 100.0 & \\
\hline
\end{tabular}

The result in table 1 shows demographic distribution of the participants with the majority of them, constituting 55 $(91.7 \%)$ to be within the ages of $18-22$ years, while $4(6.7 \%)$ are within the ages of $23-27$ years and only $1(1.7 \%)$ of the population is within the ages of 28-32 years. Therefore, it is right to conclude that majority of the class are less than 23 years of age. The result also indicates that majority of the respondents as seen from the table are females constituting 39 $(65.0 \%)$ of the research population, and males are $16(26.7 \%)$ while the remaining $5(8.3 \%)$ of the population did not fill in their gender on the questionnaires. Meanwhile, as it is, majority of the class are females. In addition, the respondents are made up of nine (9) different nationals with Turkey having 46 (76.7\%), Cyprus $7(11.7 \%)$ while the reaming seven (7) nationals have $1(1.7 \%)$ each. That gave a reasonable diversity. The respondents also were identified to speak four (4) different first languages (L1) with Turkish having 54(90.0\%), followed by Arabic with 4 (6.7\%), while Bosnien and Persian has $1(1.7 \%)$ each.

The participants' language data from the study shows the participants' level of foreign language exposure. When asked if they have ever travelled to any English speaking country, majority of the respondents indicated that they never travelled to any English speaking country. This accounted for 46 (76.7\%) of the research population. $13(21.7 \%)$ have travelled to one English speaking country or another while only $1(1.7 \%)$ did not indicate his/her position regarding travelling to English speaking country. Six (6) countries were said to have been visited by different respondents with England as the most visited English-speaking country with a frequency of 5 $(8.3 \%)$ and the remaining five (5) countries are $1(1.7 \%)$ each. Equally, only $51(85.0 \%)$ of them responded to the question of the period spend in the countries. The longest time spent in the countries visited is 8 years, which has the frequency of only one $(1.7 \%)$, while the shortest period is 3 weeks with a frequency of one $(1.7 \%)$. Others spent 2 years with second highest respondents with frequency of two $(3.3 \%)$, while the highest frequency was three $(5.0 \%)$ for 3 months and 7 months has the frequency of one $(1.7 \%)$ each. Majority of 
them spent between 3 months and 2 years in the countries they visited.

Regarding those who do watch film on the target language (English), 56 (93.3\%) do watch film on the target language, forming the majority while $3(5.0 \%)$ do not watch film on the target language, and $1(1.7 \%)$ did not indicate either of the two. Majority of them watch film on the target language. The participants use various devices to watch the film, meanwhile $39(65.0 \%)$ watch it online and considered as the most used means of watching film by the respondents. $7(11.7 \%)$ do watch it on their phones while the remaining $3(5.0 \%)$ do so on television. While 11(18.0\%) did not indicate how they watch the film. Also, regarding how often they do watch the film, $21(35.0 \%)$ state that they watch the film a couple of times in a week, $19(31.7 \%)$ do so once a week, $15(25.0 \%)$ watch a couple of times in a week, while 5(83\%) do so once a month. Therefore, more respondents watch the couple of times in a week while the least are those that watch once a month. In addition, asking if they have ever received English lesson before, $40(66.7 \%)$ say they did and $17(28.3 \%)$ said they never received lesson before, while $3(5.0 \%)$ did not indicate neither of the two. So, majority of the respondents have received at one time or the other. Majority of the respondents speak English often as $24(40.0 \%)$ of them speak often, $21(35.0 \%)$ not often and 15(25.0\%) speak it very often.

On communicating in English with people outside the school, they often speak with their English-speaking friends as indicated by $45(75.0 \%)$ of the research population, which is more than half of the research population. $8(13.3 \%)$ do speak with their tribal friends, and $5(8.3 \%)$ speak with their neighbours who do not speak their language, while $2(3.3 \%)$ did not indicate. $50(83.3 \%)$ of the research population say they speak English outside the school when they are on an outing with their friends, while $4(6.7 \%)$ speak English when they are playing games with their friends, and 2(3.3\%) speak English when they are watching film with their siblings, but $4(6.7 \%)$ of the respondents never indicated when they speak English. Then lastly, on how long or the period they have stayed in Cyprus. $6(10.0 \%)$ said they have lived in Cyprus for 18 years, $2(3.3 \%)$ said they have lived in Cyprus for 19 years, while $1(1.7 \%)$ lived for 20 years on the Island. Only $2(3.3 \%)$ indicated to have lived in Cyprus since birth while the lest period spend on the Island is 3 months which is $4(6.7 \%)$ of the research population. 2 years has the highest frequency of the number of participants who have stayed in Cyprus with 19 $(31.7 \%)$, followed by 3 years with frequency of $11(18.3 \%)$ while 15 months, 1year 3 months, 1year 5months, 20years, 4months, 4years, 5years, 9months have the lest frequency with $1(1.7 \%)$ each.

\section{$2.2 \quad$ Instruments}

Two instruments were used for the study: foreign language anxiety scale (FLCAS) by Horwtiz, Horwtiz and Cope (1986) and foreign language reading anxiety scale (FLRAS) by Saito, Garza and Horwtiz (1999). The theoretical ranges of the
FLCAS and FLRAS are from 33 to 165 and from 20 to 100. The respondents were asked to rate each item on a 5-point Likert scale ranging from ('strongly disagree' to 'strongly agree'). The factor analysis was calculated on the Foreign Language Anxiety Scale (FLCAS) and Foreign Language Reading Anxiety Scale (FLRAS) to measure the reliability and validity of the scales. To determine the international consistency of the 33-items of FLCAS and 20-items of FLRAS, Cronbach's alpha reliability statistics was calculated, providing a reliability estimate of 0.887 and 0.802 for FLCAS and FLRAS respectively, and Average Variance Extract (AVE) of $0.79242(79.242 \%)$ and $0.73198(73.198 \%)$ validity of items were determined for FLCAS and FLRAS respectively. This indicates that FLCAS and FLRAS thereafter constructed measure high internal consistency.

\subsection{Data Analysis}

The data was collected systematically through questionnaire in which sixty (60) first year students of English Language Teaching (ELT) responded. In analysing the data, foreign language classroom anxiety (FLCA) and foreign language reading anxiety (FLRA) were treated as two variables; therefore, quantitative method was adopted using descriptive statistics, SPSS version 25.

\section{RESULTS}

Research Question 1: What are the levels of foreign language classroom anxiety and foreign language reading anxiety experienced by the ELT students at Cyprus University, (Pseudonym)?

The result of the present study indicates that foreign language classroom anxiety (FLCA) is slightly different from foreign language reading anxiety (FLRA). The general language anxiety (FRCA) shows that the scale is a single construct and indicate internal consistency coefficient of 0.887 (Cronbach's alpha, $n=60$ ). The findings compare reasonably with foreign language reading anxiety which was computed on same samples showing 0.802 internal consistency coefficient. In addition, the mean and standard deviation $(\mathrm{M}=2.8683$, $\mathrm{SD}=0.52442$ ) for FLCA is slightly smaller than those of FLRA which has mean and standard deviation $(\mathrm{M}=2.8921$, $\mathrm{SD}=0.52752$ ). The low level of FLCA could be as a result of the Island been one of British former colonies and the students have the opportunity of communicating with the native speaker (see Kunt, 1997) improving their English. To determine the relationship between the FLCA and FLRA, Pearson product correlation coefficient was also used.

Table 2: Descriptive Statistics

\begin{tabular}{|c|c|c|c|}
\hline \multicolumn{2}{|c|}{} & FLCA & FLRA \\
\hline \multirow{2}{*}{$\mathrm{N}$} & Valid & 60 & 60 \\
\cline { 2 - 4 } & Missing & 0 & 0 \\
\hline \multicolumn{2}{|c|}{ Mean } & 2.8683 & 2.8921 \\
\hline \multicolumn{2}{|c|}{ Median } & 2.8636 & 2.9250 \\
\hline
\end{tabular}




\begin{tabular}{|c|c|c|}
\hline Std. Deviation & .52442 & .52752 \\
\hline Minimum & 1.65 & 1.80 \\
\hline Maximum & 4.61 & 4.30 \\
\hline Sum & 172.10 & 173.53 \\
\hline
\end{tabular}

The descriptive statistics in table 2 shows the mean for FLCA and FLRA to be 2.8683 and 2.8921 , while the median is 2.8636 and 2.9250 with the standard Deviation (SD) of 0.52442 for FLCA and 0.52752 for FLRA. The statistic description therefore shows both FLCA and FLRA are experienced by the first year under graduate students of ELT but at a very insignificant level.

Table 3 below describes the level of anxiety as being measured using the 5-point Likert scale ranging from 'strongly disagree' to 'strongly agree' showing their frequencies and percentages.

Table 3: showing Anxiety

\begin{tabular}{|c|c|c|c|c|c|}
\hline & & Frequency & Percent & $\begin{array}{c}\text { Valid } \\
\text { Percent }\end{array}$ & $\begin{array}{c}\text { Cumulative } \\
\text { Percent }\end{array}$ \\
\hline \multicolumn{6}{|c|}{ Foreign language classroom anxiety } \\
\hline \multirow[b]{5}{*}{ Valid } & Disagree & 14 & 23.3 & 23.3 & 23.3 \\
\hline & $\begin{array}{l}\text { Neither } \\
\text { Agree } \\
\text { nor } \\
\text { Disagree } \\
\end{array}$ & 38 & 63.3 & 63.3 & 86.7 \\
\hline & Agree & 7 & 11.7 & 11.7 & 98.3 \\
\hline & $\begin{array}{l}\text { Strongly } \\
\text { Agree }\end{array}$ & 1 & 1.7 & 1.7 & 100.0 \\
\hline & Total & & 100.0 & 100.0 & \\
\hline \multicolumn{6}{|c|}{ Foreign Language Reading Anxiety } \\
\hline \multirow[b]{4}{*}{ Valid } & Disagree & 15 & 25.0 & 25.0 & 25.0 \\
\hline & $\begin{array}{l}\text { Neither } \\
\text { Agree } \\
\text { nor } \\
\text { Disagree }\end{array}$ & 37 & 61.7 & 61.7 & 86.7 \\
\hline & Agree & 8 & 13.3 & 13.3 & 100.0 \\
\hline & Total & 60 & 100.0 & 100.0 & \\
\hline
\end{tabular}

The responses to FLCA and FLRA are considered in table 3 above. On the 33-items in the questionnaires were responded to for FLCA, the results show 14(23.3\%) disagree that they experience no anxiety, 38(63.3\%) are in indecisive, that is, they neither agree nor disagree and $7(11.7 \%)$ of them agree that they experience anxiety in the foreign language classroom while the remaining $1(1.17 \%)$ strongly agree to experience anxiety. Their level of anxiety experienced in the case FLCA is very low. Their experience as regarding FLRA shows that $15(25.0 \%)$ disagree to have experienced English language reading anxiety, $37(61.7 \%)$ neither agree nor disagree to experience anxiety in the foreign language reading anxiety as $8(13.3 \%)$ say that they experience anxiety in English reading class.
Table 4 describes the correlations between FLCA and FLRA as seen below:

\begin{tabular}{|r|c|c|c|}
\hline \multicolumn{4}{|c|}{ Table 4: Correlations between FLCA and FLRA } \\
\hline \multirow{3}{*}{ FLCA } & Pearson Correlation & 1 & $.666^{* *}$ \\
\cline { 2 - 4 } & Sig. (2-tailed) & & .000 \\
\cline { 2 - 4 } & $\mathrm{N}$ & 60 & 60 \\
\hline \multirow{3}{*}{ FLRA } & Pearson Correlation & $.666^{* *}$ & 1 \\
\cline { 2 - 4 } & Sig. (2-tailed) & .000 & 60 \\
\cline { 2 - 4 } & $\mathrm{N}$ & 60 & \\
\hline \multirow{2}{*}{$* * . \begin{array}{c}\text { Correlation is significant at the 0.01 level (2-tailed). } \\
\text { FLCA=foreign language classroom anxiety } \\
\text { FLRA=foreign reading anxiety }\end{array}$} \\
\hline
\end{tabular}

In establishing the relation between FLCA and FLRA, Pearson correlation was computed and it indicates that there is correlation significance $0.666^{* *}(0.01$ level $)$. Meaning, there is significant positive relationship between the FLCA and FLRA in which 33 -items and 20-items used on the sample respectively.

Research Question 2: Is there any difference in age as it affects Foreign Language Classroom Anxiety and Foreign Language Reading Anxiety?

The learners' foreign language learning anxiety is measured against their ages. The table 5 below shows the measures if there is any possibility of them experiencing anxiety in the foreign language classroom and foreign language reading.

Table 5: Age difference as it contribute to anxiety

\begin{tabular}{|c|c|c|c|c|c|}
\hline \multicolumn{7}{|c|}{} & Disagree & $\begin{array}{c}\text { Neither } \\
\text { Agree } \\
\text { nor } \\
\text { Disagree }\end{array}$ & Agree & $\begin{array}{c}\text { Strongly } \\
\text { Agree }\end{array}$ & Total \\
\hline \multicolumn{7}{|c|}{ Age FLCA Cross Tabulation } \\
\hline $18-22$ & 13 & 35 & 6 & 1 & 55 \\
\hline $23-27$ & 1 & 2 & 1 & 0 & 4 \\
\hline $28-32$ & 0 & 1 & 0 & 0 & 1 \\
\hline Total & 14 & 38 & 7 & 1 & 60 \\
\hline \multicolumn{7}{|c|}{ Age FLRA CrossTabulation } \\
\hline $18-22$ & 14 & 34 & 7 & & 55 \\
\hline $23-27$ & 1 & 2 & 1 & & 4 \\
\hline $28-32$ & 0 & 1 & 0 & & 1 \\
\hline Total & 15 & 37 & 8 & & 60 \\
\hline
\end{tabular}

Table 5 above shows the learners' FLCA as it affects age; the results indicate that 13 of those between the ages of 18-22 disagreed to have experienced anxiety; 35 neither of them neither agree nor disagree, they are assumed to neutral. Meanwhile, 6 agree to have experienced anxiety and only 1 for strongly agree to experienced FLCA. In the category of those within the ages of 23-27, 1 person expressed disagree, 2 neither agree nor disagree and 1 agree while only 1 within the ages of 28-32 participated with neither agree nor disagree. In the case of FLRA, those within the ages of 18-22 have the highest number of respondents with neither agree nor agree 
with 34 , followed by disagree with 14 and agree with 7 responses and those within the ages of 23-27 and 28-32 recording low responses having $1 \& 2,2 \& 1$ and $1 \& 0$ for disagree, neither agree or disagree and agree respectively.

Meanwhile, table 6 below displays the chi-square statistics aimed at examining if there are any significant differences between the opinions emanating from different age groups of the respondents regarding FLCA as well as regarding FLRA.

Table 6: Anxiety Chi-Square Tests

\begin{tabular}{|c|c|c|c|}
\hline & Value & Df & $\begin{array}{c}\text { Asymptotic } \\
\text { Significance (2-sided) }\end{array}$ \\
\hline \multicolumn{4}{|c|}{ FLCA Chi-Square Tests } \\
\hline Pearson Chi-Square & 1.410 & 6 & .965 \\
\hline Likelihood Ratio & 1.668 & 6 & .948 \\
\hline $\begin{array}{c}\text { Linear-by-Linear } \\
\text { Association }\end{array}$ & .081 & 1 & .776 \\
\hline N of Valid Cases & 60 & \multicolumn{3}{|c|}{} \\
\hline \multicolumn{5}{|c|}{ FLRA Chi-Square Tests } \\
\hline Pearson Chi-Square & 1.138 & 4 & .888 \\
\hline Likelihood Ratio & 1.405 & 4 & .675 \\
\hline $\begin{array}{c}\text { Linear-by-Linear } \\
\text { Association }\end{array}$ & .176 & 1 & \\
\hline N of Valid Cases & 60 & & \\
\hline
\end{tabular}

The chi-square statistics was used to examine if there is significant differences between the opinions of the different age groups of the respondents regarding FLCA. The results presented show that there are no significant differences. This is indicated by the chi-square statistics which are insignificant at 5\% level of significance. So also, the chi-square statistics was used to examine if there are significant differences between the opinions of the different age groups of the respondents regarding FLRA. The results show that there are no significant differences. This is indicated by the chi-square statistics which are insignificant at 5\% level of significance.

Research Question 3: Do their foreign language classroom anxiety and foreign language reading anxiety differ according to gender?

Gender is another variable which is very significant in this category of study as several studies like Nahavandi and Mukundan (2013), Baş and Özean (2018), Alsowat (2016), Celik (2019) and Chou (2019 have investigated it differently and presented different results as well. Table 7 below measures the anxiety experienced by different genders regarding FLCA and FLRA.

Table 7: Anxiety difference according to gender

\begin{tabular}{|c|c|c|c|c|c|}
\hline & Disagree & $\begin{array}{l}\text { Neither } \\
\text { Agree } \\
\text { nor } \\
\text { Disagree }\end{array}$ & Agree & $\begin{array}{c}\text { Strongly } \\
\text { Agree }\end{array}$ & Total \\
\hline \multicolumn{6}{|c|}{ Gender FLCA Cross tabulation } \\
\hline Male & 6 & 10 & 0 & 0 & 16 \\
\hline Female & 7 & 25 & 6 & 1 & 39 \\
\hline
\end{tabular}

\begin{tabular}{|c|c|c|c|c|c|}
\hline Total & 13 & 35 & 6 & 1 & 55 \\
\hline \multicolumn{6}{|c|}{ Gender FLRA Cross tabulation } \\
\hline Male & 5 & 10 & 1 & & 16 \\
\hline Female & 10 & 22 & 7 & & 39 \\
\hline Total & 15 & 32 & 8 & & 55 \\
\hline
\end{tabular}

The result from table 7 on FLCA indicated that 16 males responded with 6-disagree, 10-neither agree nor disagree, 0 agree and 0 -strongly respectively, while the female responses reflected 7 for disagree, 25 for neither agree nor disagree, 6 for agree and only 1 for strongly agree. In the case of FLRA, 55 respondents participated with 5 did not indicate their gender. Out this number, 5 - agree, 10 - neither agree nor disagree and only 1 - agree making a total of 16 men while for the female, 10 - disagree, 22 - neither agree nor disagree and 7 - agree to experience anxiety in FLRA bringing the female total number to 39 .

Table 8: Gender anxiety Chi-Squire Tests

\begin{tabular}{|c|c|c|c|}
\hline & Value & Df & $\begin{array}{c}\text { Asymptotic } \\
\text { Significance (2-sided) }\end{array}$ \\
\hline \multicolumn{4}{|c|}{ FLCA Gender Chi-Square Tests } \\
\hline Pearson Chi-Square & 4.711 & 3 & .194 \\
\hline Likelihood Ratio & 6.502 & 3 & .090 \\
\hline $\begin{array}{c}\text { Linear-by-Linear } \\
\text { Association }\end{array}$ & 4.362 & 1 & .037 \\
\hline N of Valid Cases & 55 & & .530 \\
\hline \multicolumn{5}{|c|}{ FLRA Gender Chi-Square Tests } \\
\hline Pearson Chi-Square & 1.271 & 2 & .484 \\
\hline Likelihood Ratio & 1.453 & 2 & .362 \\
\hline $\begin{array}{c}\text { Linear-by-Linear } \\
\text { Association }\end{array}$ & .830 & 1 & \\
\hline N of Valid Cases & 55 & & \\
\hline
\end{tabular}

The chi-square statistics was used to examine if there are significant differences between the responses of the male and female respondents regarding FLCA. The results show that there are no any significant differences. This is indicated by the chi-square statistics, which are insignificant at 5\% level of significance. Chi-square statistics was equally, used to examine if there are any significant differences between responses of the male and female respondents regarding FLRA. The results show that there are no significant differences. This is indicated by the chi-square statistics which are insignificant at 5\% level of significance. Therefore, for both FLCA and FLRA, there are no any significant differences between the level of anxiety experienced by the learners.

\section{DISCUSSION AND CONCLUSION}

The first year undergraduate students of ELT Department experience some FLCA with minimum of 1.65 and maximum of 4.61 , which is slightly above FLRA, which has minimum and maximum of 1.80 and 4.30 respectively. The two, FLCA 
and FLRA have Standard Deviation (SD 0.52442) and (SD 0.52752 ) respectively, showing the difference as insignificant, while on the average, they are same. The relationship between FLCA and FLRA is positive having a Pearson correlation significance of $0.666^{* *}(0.001$ level$)$.

The chi-square statistics was used to examine if there was any significant differences between the opinion expressed by different age groups and gender of the respondents regarding FLCA and FLRA. The general results therefore show that there are no significant differences. Based on Likelihood ratio test, the null hypothesis cannot be rejected because Asymptotic Significance (2-sided) is greater than 5\%. This, as indicated by the chi-square statistics, which is insignificant at $5 \%$ level of significance. Agreeing with Bas and Özean (2018)'s studies which showed that there was no significant difference as far as gender is concerned in terms of the students' anxiety. That gender is an ineffective variable that might not affect foreign language learners' anxiety in the classroom as well as foreign language reading anxiety. This study examined foreign language anxiety and foreign language reading anxiety, it is therefore worthwhile to make the following recommendations as certain areas which have not been covered by the current study and therefore recommend a comparative study which can be carried on anxiety level of students of different nationalities. Such study can also be conducted among students of pure sciences to determine their level of anxiety in foreign language usages.

\section{REFERENCES}

[1] Alsowat, H. (2016). An EFL Flipped Classroom Teaching Model: Effects on English Language. Higher-order Thinking Skills, Student Engagement and Satisfaction, Journal of Education and Practice, 7,108-121. www.iiste.org

[2] Atieno, O. P. (2009). An analysis of the strengths and limitation of qualitative and quantitative research paradigms, Problems of education in the 21stcentury, 13, 13-18

[3] http://www.scientiasocialis.1t/pec/node/files/pdf/Atieno_Vol.13.pd $\mathrm{f}$.

[4] Baş, G., \& Özcan, M. (2018). Foreign language learning anxiety: A comparison between high school and university students, International Journal of Human Sciences, 15, 3.

[5] Bergström, K., Klatte, M., Steinbrink, C. \& Lachmanna,T. (2016). First and Second Language Acquisition in German Children Attending a Kindergarten Immersion Program: A Combined Longitudinal and Cross-Sectional Study, Language Learning 66(2) 386-418, DOI: 10.1111/lang.12162

[6] Bolton, K., \& Kuteeva, M. (2012). English as an academic language at a Swedish university: parallel language use and the 'threat' of English. Journal of Multilingual and Multicultural Development, 33(5), 429-447. doi:10.1080/01434632.2012.670241

[7] Çağatay, S. (2015). Examining EFL students' foreign language speaking anxiety: The case at a Turkish state university, Procedia Social and Behavioral Sciences, 199, $648-656$.

[8] Celik, B. (2019). Relationship between Foreign Language Learning and Exam Stress with Gender: A Study on Tshik International University Preparatory School Students, Iraq. International Journal of Social Sciences \& Educational Studies, 5(3), 311-322, doi: $10.23918 /$ ijsses.v5i3p311.

[9] Cheng, Y. (2002). Factors Associated with Foreign Language Writing Anxiety. Foreign Language Annals, 35(6), 647-656. doi:10.1111/j.1944-9720.2002.tb01903.x

[10] Chou, M. (2019). Predicting self-efficacy in test preparation: Gender, value, anxiety, test performance, and strategies, The
Journal of Educational Research, 112(1), 61-71, DOI: 10.1080/00220671.2018.1437530

[11] Chow, B. W., Chiu, H. T., \& Wong, S. W.L. (2018). Anxiety in reading and listening English as a foreign language in Chinese undergraduate students, Language Teaching Research, 22(6), 719738, DOI: $10.1177 / 1362168817702159$.

[12] Cinkara, E. (2016). Reflective practice and foreign language classroom anxiety: video-stimulated recall at work, Reflective Practice, 17(6), 694-707, DOI: 10.1080/14623943.2016.1206880.

[13] Dewaele, J., Petrides, K. V., \& Furnham, A. (2008). Effects of Trait Emotional Intelligence and Sociobiographical Variables on Communicative Anxiety and Foreign Language Anxiety Among Adult Multilinguals: A Review and Empirical Investigation. Language Learning, 58(4), 911-960. doi:10.1111/j.14679922.2008.00482.x

[14] Elkhafaifi, H. (2005). Listening Comprehension and Anxiety in the Arabic Language Classroom. The Modern Language Journal, 89(2), 206-220. doi:10.1111/j.1540-4781.2005.00275.x

[15] Gass, S. M. (n.d.). How do learners resolve linguistic conflicts? Linguistic Perspectives on Second Language Acquisition, 183-200. doi:10.1017/cbo9781139524544.013

[16] Gurney, L. (2018). Academic English \& EMI in the Asia Pacific: Complexities, opportunities \& outcomes. In I. Liyanage (Ed.), Multilingual education yearbook 2018: Internationalization, stakeholders \& multilingual education contexts (pp. 73-90). New York: Springer.

[17] Holton, E. F. \& Burnett, M. F. (2005). The Basic Quantitative Research. In R. A. Swanson \& E. F. Holton (Eds.). Research in Organization: Foundations and Methods in Inquiry, pp. 29-44, Berret-Koehler publishers, Inc, San Francisco.

[18] Horwitz, E. K. (2010). Foreign and second language anxiety, Lang. Teach., 43(2), 154-167, doi:10.1017/S026144480999036

[19] Horwitz, E. K. (2013). Becoming a Language Teacher: A Practical Guide to Second Language Learning and Teaching. USA, Pearson

[20] Horwitz, E. K., Horwitz, M. \& Cope, J. A. (1986). Foreign language classroom anxiety. Modern Language Journal, 70, 125132.

[21] Jin, Y. X., \& Dewaele, J. (2018). The effect of positive orientation and perceived social support on foreign language classroom anxiety. System, 74, 149-157. doi:10.1016/j.system.2018.01.002

[22] Kondo, D. S. \& Ling, Y.Y. (2004). Strategies for coping with language anxiety: the case of students of English in Japan, ELT Journal, Volume 58(3), 258-265, https://doi.org/10.1093/elt/58.3.258

[23] Krashen, S.D. (1985). The Input Hypothesis: Issues and Implications, New York: Longman.

[24] Kunt, N. (1997). Anxiety and beliefs about language learning: A study of Turkish-speaking university students learning English in North Cyprus. Applied Psycholinguistics, 20,217-239. https://www.elibrary.ru/item.asp?id=5488273

[25] Luo, H. (2014). A measure of Chinese language learning anxiety: Scale development and preliminary validation, DE GRUYTER MOUTON CASLAR 2014; 3 (2), 147 - 174, https://www.researchgate.net/publication/270645668, DOI 10.1515/caslar-2014-0009.

[26] MacIntyre, P. D. (1995). How does anxiety affect second language learning? A reply to Sparks and Ganschow. Modern Language Journal, 79:1, 90-99.

[27] MacIntyre, P. D., \& Charos, C. (1996). Personality, Attitudes, and Affect as Predictors of Second Language Communication. Journal of Language and Social Psychology, 15(1), 3-26. doi: $10.1177 / 0261927 \times 960151001$

[28] Muijs, D. (2013). Introduction to Quantitative Research In: Doing Quantitative Research in Education with SPSS, SAGE Publications Ltd City: London. DOI: https://dx.doi.org/10.4135/9781849203241.

[29] Nahavandi, N., \& Mukundan, J. (2013). Iranian EFL Engineering Students' Motivational Orientations towards English Language Learning along Gender and Further Education in Language 
Institutes. International Journal of Linguistics, 5(1). doi:10.5296/ijl.v5i1.2684

[30] Oga-Baldwin, W. Q., Nakata, Y., Parker, P., \& Ryan, R. M. (2017). Motivating young language learners: A longitudinal model of self-determined motivation in elementary school foreign language classes. Contemporary Educational Psychology, 49, 140150. doi:10.1016/j.cedpsych.2017.01.010

[31] Onwuegbuzie, A. J., Bailey, P., \& Daley, C. E. (1999). Factors associated with foreign language anxiety. Applied $\begin{array}{ll}\text { Psycholinguistics, } & \text { 20(2), 217-239. }\end{array}$ doi:10.1017/s0142716499002039

[32] Saito, Y., Garza, T. J., \& Horwitz, E.K. (1999). Foreign Language Reading Anxiety, The Modern Language Journal, 83(ii), doi: 202218. 0026-7902/99/202-218.

[33] Santos, A., Cenoz, J., \& Gorter, D. (2018). Attitudes and anxieties of business and education students towards English: some data from the Basque Country, Language, Culture and Curriculum, 31(1), 94-110, DOI: 10.1080/07908318.2017.1350189.

[34] Sellers, V. D. (2000). Anxiety and Reading Comprehension in Spanish as a Foreign Language. Foreign Language Annals, 33(5), 512-520. doi:10.1111/j.1944-9720.2000.tb01995.x

[35] Tan, L. T., \& Nguyen, H. T. (2018). Internationalisation of Vietnamese universities through English medium instruction (EMI): Practices, tensions \& implications for local language policies In I. Liyanage (Ed.), Multilingual education yearbook
2018: Internationalization, stakeholders \& multilingual education contexts (pp. 91-106). New York: Springer.

[36] Toubot, A. M., Seng, G.H., \& Abdullah, A.B.A. (2018). Examining Levels and Factors of Speaking Anxiety among EFL Libyan English Undergraduate Students, IJALEL 7(5), 47-56, http://dx.doi.org/10.7575/aiac.ijalel.v.7n.5p.47

[37] Yan, J.X. \& Horwitz, E.K. (2008). Learners' Perceptions of How Anxiety Interacts withPersonal and Instructional Factors to Influence Their Achievement in English: A Qualitative Analysis of EFL Learners in China, Language Learning 58(1)151-183 https://doi.org/10.1111/j.1467-9922.2007.00437.x.

[38] Yastibaş, G. Ç. \& Yastibaş, A.E. (2015). The effect of peer feedback on writing anxiety in Turkish EFL (English as a foreign language) students, Procedia - Social and Behavioral Sciences, $199,530-538$.

[39] Young, D. J. (1991). An Investigation of Students' Perspectives on Anxiety and Speaking. Foreign Language Annals, 23(6), 539-553. doi:10.1111/j.1944-9720.1990.tb00424.x

[40] Young, D. J. (1992). Language Anxiety from the Foreign Language Specialist's Perspective: Interviews with Krashen, Omaggio Hadley, Terrell, and Rardin. Foreign Language Annals, 25(2), 157-172. doi:10.1111/j.1944-9720.1992.tb00524.x

[41] Zhao, A., Dynia, J., \& Guo, Y. (2013). Foreign Language Reading Anxiety: Chinese as a Foreign Language in the United States. The Modern Language Journal, 97(3), 765-778, DOI: 10.1111/j.15404781.2013.12032.x. 